Journal of Contemporary Research in Social Sciences

ISSN : 2641-0249

Vol. 2, No. 2, pp. 35-45

2020

Publisher: Learning Gate

DOI: 10.33094/26410249.2020.22.35.45

(C) 2020 by the authors; licensee Learning Gate

\title{
Talent Management and Organizational Effectiveness
}

\author{
Tamunomiebi, Miebaka Dagogo \\ Department of Management, Faculty of Management Sciences, Rivers, State University, Nkpolu-Oroworukwo, Port Harcourt, Nigeria. \\ Email: mdtamunomiebi@gmail.com \\ Worgu, Vivian Ogechi \\ Doctoral Candidate Department of Management, Faculty of Management Sciences, Rivers State University, Nkpolu-Oroworukwo, Port \\ Harcourt, Nigeria. \\ Email: viviworgu26@gmail.com
}

Received: 2 July 2020; Revised: 29 July 2020; Accepted: 14 August 2020; Published: 26 August 2020

\begin{abstract}
The aim of this paper is to examine talent management and organizational effectiveness. To achieve this, from literature, the concept of talent management with its dimensions of talent acquisition, talent development and talent retention as well as benefits of talent management for both the individual and the organization were examined. Also, the concept of organizational effectiveness, its measures of goal attainment, resource acquisition and internal processes were examined with the aim of showing that talent management can realistically result in organizational effectiveness. The paper adopted a literature review methodology. The findings in extant literature revealed that talent management significantly enhances organizational effectiveness. Based on extant literature, the paper concludes that talent management is a significant predictor of organizational effectiveness. In the end, it was firstly recommended that management should map out strategies to identify, attract and hire talented individuals because for organizations to perform satisfactorily and outcompete their competitors, they need to device strategies to attract and acquire the right kind of talent essential to attainment of corporate goals. Secondly, management should endeavour to marry organizational and employee interests by formulating and implementing policies and practices that favours the career development of the employee. Lastly, that management should introduce and maintain a reward(s) and recognition system as this serves as an important component in building and retaining talent(s) in an organization.
\end{abstract}

Keywords: Talent management, Organizational effectiveness, Talent acquisition, Talent development, Talent Retention, Goal attainment, Resource acquisition, Internal processes.

\section{Introduction}

Due to the complexities and stiff competition that has characterized today's dynamic and everevolving business world, organizations as result-oriented entities ideally designed to actualize predetermined goals and objectives are adopting diverse strategies to ensure organizational survival. To survive, an organization must be effective in every sense of the word as an effective organization is defined by its ability to actualize its goals and objectives. Organizations that are ineffective are often characterized with inability to accomplish set goals, inability to acquire resources required for the production process leading to poor performance and job dissatisfaction which results in lack of employee commitment.

Furthermore, uncommitted employees always exhibit some behavioural patterns that suggests that they are no longer happy with their job. Some of these tendencies exhibited by uncommitted employees are absenteeism and lateness to work, increase in employee turnover and decrease in job performance 
amongst others. As remedy to the aforementioned, an organization that is characterized with highly talented individuals aside from attaining corporate goals, maintaining a healthy relationship with the business environment in the course of acquiring resources needed for its business operations; the organization is able to stay afloat and survive the stiff competition that has characterized today's dynamic and evolving business world.

To this end, the purpose of this paper will be to examine talent management and organizational effectiveness, and the relationship that exists between both variables. To achieve this, the concept of talent management, its dimensions and benefits for both the organization and the employee as well as the concept of organizational effectiveness, its measures of goal accomplishment, resource acquisition and internal processes will be discussed with the aim of showing that talent management can realistically result in organizational effectiveness.

\section{Literature Review}

\subsection{The Concept of Organizational Effectiveness}

Barnard (1938) viewed organization as a system of consciously coordinated personal activities or forces. To him, an organization is a system that require the cooperation of human activities. He noted that an organization is birthed when there are; persons capable of communicating with each other and are willing to contribute action(s) so as to accomplish a common goal. This implies that individuals come together, assume responsibility for the tasks assigned to them so as to attain a goal that ordinarily would have been too cumbersome for a single individual to achieve on his or her own. To this end, the basic elements of an organization are; communication, willingness to cooperate and common purpose.

The concept of organizational effectiveness has been an interesting subject of discourse in organizations from time immemorial. The need to have a clear understanding of what constitutes an effective organization has culminated in the interest in the subject matter, making it almost impossible to judge an organization as being more effective than the other especially as what constitutes effectiveness in an organization may be viewed differently in another organization. In the light of this, several authors have written on the concept of organizational effectiveness on the basis of their perception of the subject matter but this paper simply views organizational effectiveness as an organization's ability to survive and make progress in its business environment through the attainment set goals and objectives. Georgopoulos and Tannenbaum (1969) define organizational effectiveness as the extent to which an organization as a social system, given certain resources and means, fulfills its objectives without in- capacitating its means and resources, and without placing undue strain upon its members.

\subsection{Measures of Organizational Effectiveness}

Following the intrigues that the concept of organizational effectiveness has generated, the issue of its measures has always been in contest. This is unconnected to the arguments from certain quarters that what constitutes effectiveness in an organization may not likely constitute effectiveness in another organization. It is on this premise that goal accomplishment, resource acquisition, internal processes and strategic constituencies satisfaction amongst others have been identified as measures of organizational effectiveness but this paper will focus on goal accomplishment, resource acquisition and internal processes as measures of organizational effectiveness.

\subsection{Goal Accomplishment}

Every organization sets clear goals that are expected to be met within a period of time. These goals could be long term or short term depending on what the organization seeks to achieve. Hence, organizations periodically set goals to enable them measure their performance, productivity and ultimately profitability as that is the primary purpose of every business. Eydi (2015) posit that the goals attainment approach defines effectiveness in relation to the organization's success in realizing its set goals. Organizations as naturally goal-oriented entities are perceived to be effective when set goals are 
accomplished. This approach looks at the goals and outputs of an organization and how well an organization meets its set goals. This is because organizations are established for the sole purpose of pursuing one goal or the other at every point in time.

Manu (2016) opine that management always compares key organizational outcomes with previously stated goals and corrective action is initiated for any kind of deviation. This implies that measuring organizational outcomes with previously stated goals and applying corrective measures where needed helps to attain newly set goals and promote organizational effectiveness. This is necessary following an organization's need to be grow. Although Eydi (2015) argue that due to the complex nature of today's organizations, there may be need for an organization to set multiple goals which may conflict each other creating a confusion as to what an organization sometimes want to achieve, this too may result in organizations inability to achieve anything in the long run. However, it is imperative to note firstly that organizations are naturally goal-oriented hence it is practically impossible to rule out goal attainment as a measure of organizational effectiveness. Secondly, goals are always clear and specific in nature making it unlikely that two goals will conflict each other although it can be agreed that the methods employed in achieving them may be conflicting.

\subsection{Resource Acquisition}

Resource acquisition approach otherwise known as system resource approach is centred on the ability of the organization to exploit its environment in order to acquire scarce and valued resources that are essential to the production processes (Yuchtman \& Seashore, 1967) in Eydi (2015). This implies that when goals are set, there is need to assemble resources from the environment so as to bring the goal to fruition, that is, the greater the resources acquired from the environment by the organization, the greater possibility that the organization will attain its corporate goals.

Manu (2016) assert that resource acquisition is appropriate when inputs have a traceable impact on the outputs. An organization is perceived to be effective when it is able to assemble factors of production like capital, labour and technical and managerial expertise which are key for the production of goods and services, and these factors of production assembled should have direct impact on organizational outputs. This is so because resources need to be acquired in order to attain organizational goals. Hence, this approach views an organization to be effective by its ability to generate resources from the environment and maintain a harmonious relationship with the environment because for the organization to survive it is necessary that it acquires a steadyflow of resources from its environment as they are consumed (Kast \& Rosenzweig, 1985) and failure to acquire these resources may result in the organization tending toward an entropic state.

\subsection{Internal Processes}

For an organization to be healthy, information has to flow smoothly and employee loyalty, commitment, job satisfaction and trust must prevail (Manu, 2016).Organizations must have free flow of information, and members of the organization must be emotionally attached to each other in such a way that they are free to communicate their fears and failures with each other in order to be ensure improved performance. Also, employees must be satisfied with their job thereby resulting in loyalty and commitment to the organization. This approach is also referred to as healthy systems approach. Nafei (2015) assert that in order to survive and compete in the marketplace, every organization should have a process to respond to its needs for talented people. This is premised on the general knowledge that though human resources constitute the livewire of every organization, it is important that an organization's workforce is comprised of the best talented individuals.

\subsection{The Concept of Talent Management}

Organizations are birthed as a result of the need to perform tasks which are too cumbersome for a single individual to perform. Hence, organizations from time to time are saddled with the enormous responsibility of bridging their talent gap by attracting, hiring and retaining individuals who possess 
the requisite skills and competencies essential to the actualization of organizational goals and objectives. Talent refers to an innate giftedness, which is regarded as a gift (Tansley, 2011).

Burkus and Osula (2011) believe that talent is innate and as such it can be identified and developed at an early stage. Collings and Mellahi (2009) assert that talent management strategy are activities and processes that involve the systematic identification of key positions which differentially contribute to the organization's sustainable competitive advantage, the development of a talent pool of high potential and high performing incumbents to fill these roles, and the development of a differentiated human resource architecture to facilitate filling these positions with competent incumbents and to ensure their continued commitment to the organization.

It is a truism that human resources constitute the livewire of every organization following their roles in the actualization of pre-determined goals. Hence, organizations while constituting their workforce constantly search the job markets to secure the best individuals with potentials relevant to their corporate goals, and also to enjoy other benefits that can be derived from having a talented workforce. Borisova, Silayeva, Saburova, Belokhvostova, and Sokolova (2017) posit that talent management is a branch of HR dealing with search for and attraction of efficient employees, integration of new personnel, motivation and support for employees in order to achieve the current corporate goals.

Talent management is an organization's ability to attract, hire and retain individuals with skills and competencies that will carter for the organization's present and future needs. Ali, Bashir, and Mehreen (2019) assert that talent management refers to the anticipation of required human capital for an organization and the planning to meet potential needs. Campbell and Hirsh (2013) view talent management as the best human resources in an organization whose performance highly influence the organization's overall performance.TM is the sourcing (finding talent), screening (sorting of qualified and unqualified applicants); selection (assessment/testing, interviewing, reference/background, checking, of applicants) on-boarding (offer generation/acceptance, badging/security, payroll, facilities; retention measures to keep the talent that contributes to the success of the organization); development (training growth, assignments); deployment (optimal assignment of staff to projects, lateral opportunities, promotions) and renewal of the workforce with analysis and planning as the adhesives, overarching ingredient (Brewster, Carely, Grobler, Holland, \& Warnich, 2010).

Talent management is identifying mission-critical values, competencies and talents needed in the current and future workforce; clarifying the methods that will be used to recruit, hire, develop, manage and retain a high performing workforce (Mendes \& Stander, 2011).It is beneficial to both the employee and the organization. To the organization, talent management helps to increase organizational productivity, ensures growth and innovation as well as establishing a high performance workforce while for the employee, talent management helps to develop their skills and competencies thereby guaranteeing job satisfaction from their work. Borisova et al. (2017) argue that talented employees must certainly possess high potentials, be able to adapt to operational processes, and know the work process perfectly. This implies that for an employee to be considered as talented, such employee must have very high potentials and possess the ability to adjust to the organization's processes as well the required technical know-how for the job.

\subsection{Dimensions of Talent Management}

Talent management dimensions include talent acquisition, talent development, talent engagement, talent retention but this paper will focus on talent acquisition, talent development and talent retention as dimensions of talent management.

\subsection{Talent Acquisition}

Organizations promote their values in order to attract talented individuals to apply to join the organization. Talent acquisition refers to the process of attracting, recruiting, selecting and employing talents in an organization. Ra'ed, Haneen, Yasar, and Bader (2018) argue that tracking talents and attracting them must be integrated with the management's overall strategies. Management must be 
aware of the kind of talent that they need and device strategies to attract these talents to the organizations. Garg and Rani (2014) assert that talent management begins with identification and recognition of individuals for their unique strengths. They opine that talent acquisition entails workforce planning, recruitment and selection. Planning is a composition of how appropriate individuals are selected on the basis of their skills, knowledge, pragmatism, maturity and ensuring that they are smoothly fitted into their assigned roles as well as the overall system.

The HR department is often charged with the responsibility of recruitment and selection because they constitute the competitive advantage a firm has over others. The firm decides on the positions to be filled through manpower planning, carrying out job analysis, developing the job description, and job specification. Talented individuals are brought into the organization through an integrated process of recruiting, assessment, evaluation, and hiring. Remuneration also plays a significant role in attracting knowledgeable people, and the best way to attract such a valuable asset is by following what is called employer branding. This type of branding shows the organization's efforts in building a strong and unique image about it and installing this image in the minds of its employees to keep them and in the minds of the desired talented candidates to attract them (Hung, 2013).This implies that when organizations pay employees' salaries and wages that commensurate with their inputs in the organization (fair reward system), they overtime build a corporate image which helps in attracting the right kind of talent to the organization.

\subsection{Talent Development}

As soon as an employee is hired, it becomes imperative to adapt to the organization's culture. The employee at this point is availed the opportunity to develop new skills while sharpening the set of skills he has already, this is done to ensure that the employee performs his current job optimally and prepares for higher responsibility in the future. Organizations overtime utilize programs like induction, career planning, mentoring, training, autonomy, coaching, performance appraisal as well as feedback to develop talent management.

Ra'ed et al. (2018) posit that talent development starts with a performance appraisal and evaluation, by which an individual's strengths and weaknesses are assessed and training needs are pinned down, providing the needed feedback for learning programs and career planning. This means that organizations initiate talent development by simply evaluating the strengths and weaknesses of the employees in relation to their performance, observe areas where they need to be trained and train them accordingly in order to ensure improvements on their career plans.

Thunnissen (2016) assert that when management is able to marry their concern for employees and the organizational interests, employees tend to be motivated in the development phase with certain practices that eventually boosts employees' professional development and involvement. This is basically why it is the duty of the organization to create a clear career path so talent will be attached to future needs (Nobarieidishe, Chamanifard, \& Nikpour, 2014). Organizations that create the right platform for employee career development tend to successfully attract, motivate and retain their employees especially as employees will be highly motivated and committed to their jobs.

Garg and Rani (2014) argue that an organization must train and enable employees to become productive and integrated into the company more quickly. A carefully designed placement system improves employee morale, which in turn reduces employee turnover and absenteeism. Also, they believe that training mechanism improves the knowledge, skills and the performance of the employee. Most of the organizations identify specific training needs prior to training its people. Once the training needs are identified, development of the training objectives should be carried out. Trained and developed talents have a greater probability of staying and growing in an organization.

\subsection{Talent Retention}

Talent retention refers to the retention of skilled and talented individuals in the organization for a long period of time. One of the key roles of HR is to ensure that employees with right skills and talent 
sticks with the organization for a very long period of time (Ifeoma, Purity, \& Okoye-Nebo, 2015). Attracting and hiring talented individuals is good for an organization but it is most important to retain these talents for as long as possible. This is because retaining talents in an organization impacts greatly on an organizations return on investment that is why organizations devise various strategies to retain talents for a long period of time.

Some of these strategies include career planning, long term incentives, positive working environment and flexible working arrangements amongst others. Ahmadi, Ahmadi, and Abbaspalangi (2012) assert that talent leadership, commitment, value, communication, as well as incentive programs like giving rewards or compensation of valuable services rendered by the employee constitutes the factors that affect talent retention.

\subsection{Benefits of Talent Management}

Garg and Rani (2014) affirm that talent management is immensely beneficial to both the organization and the employee. To the organization, talent management offers the following benefits:

1. Increase productivity and capability.

2. A better linkage between individual's efforts and organizational goals.

3. Commitment of valued employees.

4. Reduced employee turnover, increased bench strength and a better fit between people's jobs and skills.

To the employee, talent management offers the following benefits:

1. High motivation and commitment.

2. Career development.

3. Increasing knowledge about and contribution to corporate goals.

4. Sustained job satisfaction.

\section{Conceptual Framework}

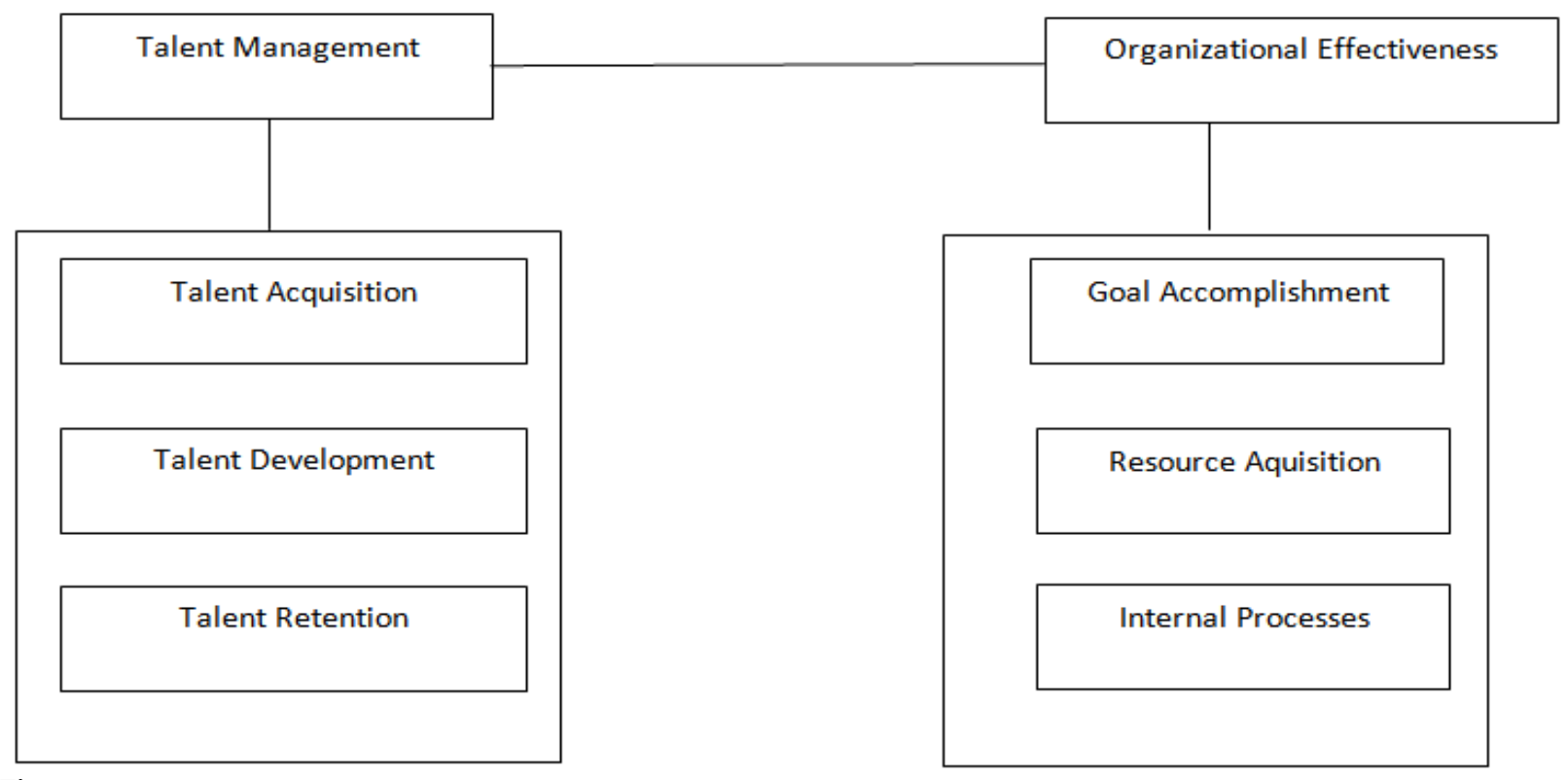

Figure 1.

Conceptual framework for talent management and organizational effectiveness. 
The framework takes a linear relationship between the predictor variable on the left hand side and the criterion variable at the right hand side. The conceptual framework shows that organizational effectiveness is a function of talent management. From the conceptual framework, organizational effectiveness is measured by the level of goal accomplishment, resource acquisition and internal processes. In the same vein, dimensions of talent management include talent acquisition, talent development and talent retention.

\section{Relationship between Talent Management and Organizational Effectiveness}

Ali. and Mehreen (2018) posit that having the right talent is the greatest benefit for every organization. This is not unconnected to the benefit of competitive advantage that an organization derives from having a talented workforce especially in this present era of globalization and stiff competition. Effective talent management policies and practices are those policies and practices that show commitment to employees, resulting in higher employee engagement and lower employee turnover, thereby impacting positively on organizational productivity and effectiveness (Ali et al., 2019; Beheshtifar, Nasab, \& Moghadam, 2012). Ferreira, Neira, and Vieira (2012) affirm that talent management is the implementation of integrated strategies designed to raise employees' productivity by developing processes for attracting, developing, retaining, and utilizing people with the required skills and aptitude to meet the current and the future business needs.

In this competitive era, it is quite difficult to retain talented employees because of high mobilization of employees from one organization to the other (Kehinde, 2012). This implies that while organizations adopt talent management strategies to ensure improved organizational performances and ultimately attainment of organizational goals, it is pertinent for the organizations to formulate talent management policies and practices that favours the employees as well. This is necessary because it serves as an important avenue to secure the commitment of employees as retaining a talented workforce can be a quite challenging task to accomplish following the highly competitive era that businesses have been ushered in to and the need for a highly talented workforce to survive.

With the stiff competition faced by businesses due to globalization, it is important to know about the right talent for organizational effectiveness (Ali \& Mehreen, 2018).Organizations should promote a friendly work environment where work is organized in such a way that it enables the organization to be aware of the existing and potential talent that is and will be needed in the organization (Kock \& Ellstrom, 2011; Nilsson \& Ellstrom, 2012). This implies that following the evolving and dynamic nature of today's business world, having a good knowledge of the kind of talent that an organization needs or will require in the nearest future to perform maximally and taking appropriate steps to attract, hire and retain these talents will not only help the organization actualize pre-determined goals but also help an organization survive in a stiff competitive business environment.

Lyria, Namusonge, and Karanja (2017) studied the relationship between talent management and organizational performance and found that talent management creates a competitive edge which directly improves organizational performance, ultimately translating into organizational effectiveness. In the same vein, Ali et al. (2019) studied how to manage organizational effectiveness through talent management and career development: they found that career development as a talent management strategy enhances employee engagement level which in turn improves organizational effectiveness. Also, Ali and Brandl (2017) theoretically studied HRM perspectives in Pakistan and found that talent management practices create the competitive advantage which subsequently improves organizational effectiveness. Sharma, Garg, and Singh (2012) observing talent management as a concept that needs attention, opined that organizations as a matter of necessity need to focus on their core competencies and competitors. The essence of this is to capitalize on their core competencies to gain competitive advantage over their rivals and the ability to achieve the aforementioned, portends organizational success and survival in the long run. 


\subsection{Talent Acquisition and Organizational Effectiveness}

Organizations are birthed as a result of the need to perform tasks that cannot be performed by a single individual. Organizations as result-oriented entities are poised to achieving a set goal per term. The ability to achieve these set goals is often used as a yardstick to measure organizational effectiveness. To be effective, an organization's workforce should comprise of talented individuals who possess the requisite skills, knowledge, competence and maturity required to carter for an organization's present and future needs. Garg and Rani (2014) assert that talent management begins with identification and recognition of individuals for their unique strengths. They opine that talent acquisition entails workforce planning, recruitment and selection.

Workforce planning is a composition of how appropriate individuals are selected on the basis of their skills, knowledge, pragmatism, maturity and ensuring that they are smoothly fitted into their assigned roles as well as the overall system. Ra'ed et al. (2018) posit that tracking talents and attracting them must be integrated with the management's overall strategies. This implies that as organizations set out want they want to achieve and the courses of actions to be taken in order to achieve their goals, it is imperative that they look out for individuals with the requite skill and competencies required to successfully execute their chosen courses of action. Thus, for organizations to perform satisfactorily and out-compete their competitors, they need to device strategies to attract and acquire the right kind of talent essential to attainment of corporate goals.

\subsection{Talent Development and Organizational Effectiveness}

The moment a talented individual has been hired in an organization, it is important for the organization to ensure that the employee adapts to the organization's modus operandi, that is, the employee should be abreast with how things are done in the organization. This affords the employee the opportunity to learn new skills while sharpening already existing skills. This is aimed at ensuring that the employee performs optimally in his present job thereby increasing organizational performance and effectiveness.

Garg and Rani (2014) affirm that talent management highly motivates the employee and cause him or her to be committed to the organization. They also noted that talent management sets the employee on the path of career development especially as it increases the employees' knowledge about the organization and his contributions to the attainment of corporate goals, this in the long run sustains the employees' motivation, promotes job satisfaction and results in organizational effectiveness.

Ra'ed et al. (2018) argue that talent development starts with a performance appraisal and evaluation, by which an individual's strengths and weaknesses are assessed and training needs are pinned down, providing the needed feedback for learning programs and career planning. Thunnissen (2016) assert that when management is able to marry their concern for employees and the organizational interests, employees tend to be motivated in the development phase, thereby boosting employees' professional development and involvement.

This implies that employees as beings that have aspirations and desires to grow in their chosen career paths, when given the opportunity to develop their talent in the organization, they become convinced that they are in a fair exchange and this makes them tobecome highly motivated and committed to the attainment of an organization's goals and the attainment of corporate goals translates to organizational effectiveness.

\subsection{Talent Retention and Organizational Effectiveness}

Ahmadi et al. (2012) assert that talent leadership, commitment, value, communication as well as incentive programs like giving rewards or compensation of valuable services rendered by the employee constitutes the factors that affect talent retention. This means that an organization should strive to retain the talented individuals as much as it strives to attract and hire them in the first place. Therefore, it is important for an organization to adopt various strategies like functional communication mechanism and compensation plan that commensurate with employee input in the organization. This is aimed at 
not only retaining the employees but also enjoying increased productivity and capability, better linkage between individual's efforts and organizational goals, commitment of valued employees as well as reduced turnover, increased bench strength and a better fit between people's jobs and skills.

Asrar, Azhar, and Hussain (2018) posit that employee retention has an effect on organization's success. This is due to the reduction in employee turnover, increase in employee motivation and commitment to the organization following the employee's satisfaction with the job and general stability that an organization enjoys when they are able to retain their talented employees. Ifeoma et al. (2015) assert that retaining employees with the right skill and talent for a long period of time in an organization is the major role of the HR. This is as a result of the immense benefit to be derived from talented workforce. It is imperative to note that the core purpose of every organization is to make return on investment; with highly skilled and talented workforce, an organization is bound to experience increase in employee performance and attainment of pre-determined goals, resulting in organizational effectiveness.

\section{Conclusion and Recommendations}

Organizations are ideally established to pursue one goal or the other at every given point in time. To successfully pursue these goals and achieve them, there is need for individuals to come together and channel their efforts toward the attainment of a common goal. It is a truism that human resources constitute the most important resource of an organization following the all-important role they play in the attainment of organizational goals and objectives. That is why organizations often hire the best talented to achieve their corporate goals. The stiffening business environment has made it pertinent for every organization to attract, hire and retain a talented workforce so as to outcompete their competitors and achieve organizational success. This supports the position of Lyria et al. (2017) that talent management helps every member of the workforce to increase their output for the growth of the organization.

Talent management offers immense benefits to both the organization and the employees. To the organization, talent management increases productivity and capability, offers a better linkage between individual's efforts and organizational goals, ensures commitment of valued employees and reduces turnover, increases bench strength and a better fit between people's jobs and skills. While to the employee, talent management offers high motivation and commitment, opportunities for career development, increasing knowledge about the organization and contribution to organizational goals, and sustained job satisfaction. As asserted by Garg and Rani (2014) talent management begins with identification and recognition of individuals for their unique strengths. They affirm that talent acquisition entails workforce planning, recruitment and selection. Thus, as organizations set out what they want to achieve and the courses of actions to be taken in order to achieve their goals, it is imperative that they look out for individuals with the requite skill and competencies required to successfully execute the chosen action plans. This is necessary because for organizations to perform satisfactorily and outcompete their competitors, they need to device strategies to attract, acquire and retain the right kind of talent essential to attainment of corporate goals.

Once employees are hired, it is important for them to adapt to the organization's culture. The employee at this point develops new skills while sharpening the set of skills he has already, this is done to ensure that the employee performs his current job optimally and prepares for higher responsibility in the future. Organizations initiate talent development by simply evaluating the strengths and weaknesses of the employees in relation to their performance, observe areas where they need to be trained and get them trained in order to improve on their career plans.

Talent retention refers to the retention of skilled and talented individuals in the organization for a long period of time. Organizations device various strategies like adequate compensation plan and opportunities of career development to gain employee satisfaction with the job resulting in employee motivation and commitment to attainment of corporate goals. Retaining talents in an organization 
impacts greatly on an organization's return on investment, that is why organizations devise various strategies to retain talents for a long period of time.

The paper thus recommends firstly, that management should set out what they want to achieve and the courses of actions to be taken in order to achieve their goals as well as look out for individuals with the requite skill and competencies required to successfully execute the chosen action plans. Therefore, management should map out strategies to identify, attract and hire talented individuals because for organizations to perform satisfactorily and outcompete their competitors, they need to device strategies to attract, acquire and retain the right kind of talent essential to attainment of corporate goals.

Secondly, management should endeavour to marry organizational and employee interests by formulating and implementing policies and practices that favours the career development of the employee. This is aimed at not only improving employee performance but also catering for the psychological needs of the employees. This further motivates and commits the employee to the attainment of corporate goals.

Lastly, that management should introduce and maintain a rewards and recognition system as this serves as an important component to building and retaining talent in an organization. The essence of this is to cater for the physiological needs of the employees and ensure that the work environment is stabilized and armed with talented individuals in order for the organization to record meaningful progress.

\section{References}

Ahmadi, A. A., Ahmadi, F., \& Abbaspalangi, J. (2012). Talent management and succession planning. Interdisciplinary Journal of Contemporary Research in Business, 4(1), 215-218.

Ali, Z., Bashir, M., \& Mehreen, A. (2019). Managing organizational effectiveness through talent management and career development: The mediating role of employee engagement. Journal of Management Sciences, 6(1), 62-78. Available at: https://doi.org/10.20547/jms.2014.1906105.

Ali, Z., \& Mehreen, A. (2018). Understanding succession planning as a combating strategy for turnover intentions. Journal of Advances in Management Research, 16(2), 216-233. Available at: https://doi.org/10.1108/jamr-09-2018-0076.

Ali, Q., \& Brandl, J. (2017). HRM research in Pakistan: Existing approaches and future directions. Journal of Management Sciences, 4(2), 170-192. Available at: https://doi.org/10.20547/jms.2014.1704203.

Asrar, Z., Azhar, T., \& Hussain, M. (2018). Effect of talent management on the success of organization development. Archives of Business Research, 6(3), 90-103. Available at: https://doi.org/10.14738/abr.63.4075.

Barnard, C. I. (1938). The functions of the executive. Cambridge, MA: Harvard University Press.

Beheshtifar, M., Nasab, H., \& Moghadam, M. (2012). Effective talent management: A vital strategy to organizational success. International Journal of Academic Research in Business and Social Sciences, 2(12), 227-234. Available at: https://doi.org/10.4018/978-1-5225-1961-4.cho16.

Borisova, O. N., Silayeva, A. A., Saburova, L. N., Belokhvostova, N. V., \& Sokolova, A. P. (2017). Talent management as an essential element in a corporate personnel development strategy. Academy of Strategic Management Journal, 16(1), 3234.

Brewster, C., Carely, L., Grobler, P., Holland, P., \& Warnich, S. (2010). Contemporary issues in human resources management, gaining a competitive advantage (3rd ed.). South Africa: Oxford.

Burkus, D., \& Osula, B. (2011). Faulty intel in the war for talent: Replacing the assumptions of talent management with evidence-based strategies. Journal of Business Studies Quarterly, 3(2), 1-9.

Campbell, V., \& Hirsh, W. (2013). Talent management: A four step approach. UK: Institute for Employment Studies Sovereign House, Church Street, Brighton BN1, 1 UJ.

Collings, D. G., \& Mellahi, K. (2009). Strategic talent management: A review and research agenda. Human Resource Management Review, 19(4), 304-313. Available at: https://doi.org/10.21275/v5i1.nov152625.

Eydi, H. (2015). Organizational effectiveness models: Review and apply in non-profit sporting organizations. American Journal of Economics, Finance and Management, 1(5), 460-467.

Ferreira, P., Neira, I., \& Vieira, E. (2012). The strategic approach to the high-performance paradigm: A European perspective. Procedia-Social and Behavioral Sciences, 58, 474-482. Available at: https://doi.org/10.1016/j.sbspro.2012.09.1024.

Garg, D., \& Rani, K. (2014). Talent management: Empirical research results. International Journal of Management and Commerce Innovations, 2(1), 289-295.

Georgopoulos, B. S., \& Tannenbaum, A. (1969). A study of organizational effectiveness. American Sociological Revierw, 22(5), 534540.

Hung, A. (2013). Understanding talent attraction: Perceived attractiveness of financial reward elements. A Master Dissertation of Commerce in Organizational Psychology, Faculty of Commerce University of Cape Town. 
Ifeoma, O. R., Purity, N.-O., \& Okoye-Nebo, C. (2015). Effective talent management: Key to organisational success. Journal of Policy and Development Studies, 289(1850), 1-12.

Kast, F. E., \& Rosenzweig, J. E. (1985). Organization and management: A systems and contingency approach (4th ed.). New York: McGraw-Hill.

Kehinde, J. S. (2012). Talent management: Effect on organizational performance. Journal of Management Research, 4(2), $178-186$.

Kock, H., \& Ellstrom, P.-E. (2011). Formal and integrated strategies for competence development in SMEs. Journal of European Industrial Training, 35(1), 71-88.

Lyria, R. K., Namusonge, G., \& Karanja, K. (2017). Role of talent management on organisation performance in companies listed in Nairobi securities exchange in Kenya. Journal of Human Resource and Leadership, 1(3), 1-17.

Manu, M. J. (2016). Organizational behaviour. India: Kalyani Publishers.

Mendes, F., \& Stander, M. W. (2011). Positive organisation: The role of leader behaviour in work engagement and retention. SA Journal of Industrial Psychology, 37(1), 1-13. Available at: https://doi.org/10.4102/sajip.v37i1.900.

Nafei, W. A. (2015). Talent management and health service quality from the employee perspective: A study on teaching hospitals in Egypt. American International Journal of Social Science, 4(1), 91-93.

Nilsson, S., \& Ellstrom, P. E. (2012). Employability and talent management: Challenges for HRD practices. European Journal of Training and Development, 36(1), $26-45$.

Nobarieidishe, S., Chamanifard, R., \& Nikpour. (2014). The relationship between talent management and organizational commitment in international division of tejarat bank, Iran. European Online Journal of Natural and Social Sciences, 3(4), 1116-1123.

Ra'ed, M., Haneen, Y., Yasar, S., \& Bader, O. (2018). Reviewing the literature of the effect of talent management on organizational effectiveness. Journal of Social Sciences, 7(2), 140-148.

Sharma, S., Garg, B., \& Singh, K. (2012). Driving forces and emerging challenges in talent management: A pathway to organizational success. International Journal of Advanced Research in Computer Science and Software Engineering, 2(6), 117-121.

Tansley, C. (2011). What do we mean by the term "talent" in talent management? Industrial and commercial training. Emerald Group Publishing, 43(5), 66 - 274 .

Thunnissen, M. (2016). Talent management: For what, how and how well? An empirical exploration of talent management in practice. Employee Relations, 38(1), 57-72. Available at: https://doi.org/10.1108/er-08-2015-0159.

Yuchtman, E., \& Seashore, S. E. (1967). A system resource approach to organizational effectiveness. American Sociological Review, 891-903. Available at: https://doi.org/10.2307/2092843.

Journal of Contemporary Research in Social Sciences
ISSN : 2641 -O249
Vol. 2, No. 2 , pp. $35-45,2020$
DOI: $10.33094 / 26410249.2020 .22 .35 .45$
C) 2020 by the authors; licensee Learning Gate

